\title{
Espinosa, Kelsen e a natureza da norma jurídica
}

\author{
Diogo Pires Aurélio
}

Universidade Nova de Lisboa 

Comme dans la constitution de l'homme l'action de l'âme sur le corps est l'abîme de la philosophie, de même l'action de la volonté générale sur la force publique est l'abîme de la politique dans la constitution de l'État. C'est là que tous les

législateurs se sont perdus.

Rousseau, Manuscrito de Genebra

I

$\mathrm{Na}$ imensidão de tópicos que tem merecido, ao longo das últimas décadas, a atenção dos estudiosos de Espinosa, a possibilidade de uma aproximação entre a sua filosofia e a obra de Kelsen passou praticamente despercebida. Seja porque o tema específico do direito em Espinosa, pelo menos na leitura que prevaleceu a partir do século XIX, se subordina à questão global do político; seja porque o formalismo kelseniano tem toda a aparência de uma doutrina situada nos antípodas do espinosismo, onde o direito se define quer pela «potência de cada um» (o direito natural), quer pela «potência da multidão» (o direito civil); a verdade é que a aproximação entre os dois autores só recentemente foi alvo de alguma, se bem que rara, curiosidade, pese embora os diversos aspetos em que as obras de um e outro se cruzam¹. Mais surpreendente ainda, nem sequer o próprio Kelsen parece alguma vez ter suspeitado das afinidades que podem assinalar-se entre a sua concepção do direito e aquela que, embora num quadro metafísico totalmente diferente, se encontra na obra de Espinosa. Não admira, por isso, a observação pertinente que Antonio Negri fez, em 1985, a este propósito: "É estranho que Hans Kelsen, o mais importante e o mais coerente teórico dos problemas da validade e da eficácia na unidade do ordenamento jurídico, não tenha,

1 Exemplo flagrante dessa omissão pode ver-se na obra coletiva, organizada por Olivier Bloch, sobre as leituras de Espinosa no último século - Spinoza au XXe Siècle, Paris, PUF, 1993 -, que é sem dúvida uma notável coleção de textos, onde alguns dos principais espinosistas das últimas décadas confrontam o autor da Ética com autores tão diversos como Schmitt, Freud, Heidegger, Russel, Deleuze, Derrida, e onde não se encontra menção alguma a Kelsen. 
que eu saiba, procurado em Espinosa o mais leve sinal de uma antecipação"2 (Negri, 1985, p. 173). O silêncio de Kelsen a respeito de Espinosa, autor que o jurista menciona apenas uma vez na sua obra, em O problema da soberania, onde é vagamente associado ao «monismo» que Hegel viria depois a teorizar, parece tanto mais injustificado quanto o filósofo de Amesterdão estava longe de poder considerar-se um desconhecido no ambiente intelectual de Weimar. Carl Schmitt, por exemplo, logo em 1921, na famosa obra sobre a ditadura, evidencia as marcas de espinosismo que são visíveis na distinção que o Abbé Sieyes estabelece entre poder constituinte e poder constituído. Afirma, com efeito, Schmitt:

A ideia da relação entre poder constituinte e poder constituído encontra o seu analogon sistemático e metodológico perfeito na ideia da relação entre natura naturans e natura naturata, e mesmo se esta ideia é retomada do sistema racionalista de Espinosa, isso prova precisamente que este sistema não é só racionalista. Porque a teoria do poder constituinte é sempre ininteligível como racionalismo puramente mecanicista. (Schmitt, 2000, p. 147)

Alguns anos mais tarde, num texto dedicado ao Leviathan, o mais conhecido dos críticos de Kelsen analisa os capítulos XIX e XX do Tratado Teológico-Político (a seguir, TTP), vendo aí o início e a fonte das ideias liberais, de onde haveriam de brotar os germes da desagregação do Estado e, implicitamente, as raízes da crise já então patente na República de Weimar. Escreve Schmitt:

Em Hobbes a paz pública e o direito da potência soberana estava em primeiro plano; a liberdade individual de pensar ficava apenas como possível, como uma restrição última e em pano de fundo. Pelo contrário, a partir de agora, a liberdade individual de pensar torna-se o princípio formador, e as

2 No mesmo ano, foi publicado o artigo de Manfred Walther "Spinoza und der Rechtspositivismus". 
necessidades da paz pública, tal como o direito da potência estatal soberana, transformam-se em simples restrições. Um ligeiro movimento do pensar - uma comutação - provindo da existência judia, e em apenas alguns anos, com uma lógica perfeitamente consequente, a reviravolta decisiva no pensamento do Leviatã estava dada. (Id., 2002, p. 118)

Qualquer destas referências a Espinosa dificilmente poderia não ser do conhecimento de Kelsen, ele próprio judeu, ligado a meios judeus e, sobretudo, leitor de Schmitt. Mas não era apenas Schmitt, uma vez que Leo Strauss também havia já publicado, desde 1924, em revistas de Berlim e de Munique, diversos textos sobre Espinosa, no primeiro dos quais (Strauss, 1991) se pode ler uma defesa do autor do TTP contra os ataques, algo violentos e até ad hominem, que lhe havia feito, alguns anos antes, um outro judeu, de seu nome Hermann Cohen. Este último, partindo do pressuposto que as teses do TTP se explicariam, em última análise, pelo fato de o autor, quando jovem, ter sido expulso da sinagoga, reduz integralmente a filosofia de Espinosa ao panteísmo e ao formalismo:

Espinosa é um escolástico com fórmulas novas: natureza, necessidade, lei natural. (...) O seu escolasticismo não se manifesta unicamente no formalismo da sua construção e pela sua terminologia, mas diretamente, de uma forma ainda mais nítida, pela sua ausência de interesse face ao problema moderno do direito e do Estado. (...) Quaisquer que sejam as diferenças que possam encontrar-se entre Espinosa e os dois autores ingleses [Bacon e Hobbes], no essencial ele agarra-se, em matéria de direito, à potência, da mesma forma que associa as leis à indução. Não tem admiração pela Revolução Inglesa. Não tem olhos para as forças do povo que trabalham duramente, nas camadas subterrâneas da vida do Estado. (Cohen, 1991, pp. 156-157)

Cohen, porém, não é só um judeu, como Kelsen e Strauss, entre muitos que vão posicionar-se no interminável debate que se trava, por mais de um século, no interior da comunidade hebraica, 
em torno da figura e da filosofia do 'herege', considerado por alguns o seu maior inimigo. Cohen é, reconhecidamente, o chefe de fila da Escola de Marburg, cujos membros defendem um "retorno a Kant" e que marcará decisivamente a filosofia alemã de finais do século XIX, princípios do século XX. Em sua opinião, à semelhança do que Kelsen virá também a defender mais tarde, um conhecimento universal, válido, ocorre unicamente quando o objeto do conhecimento é determinado pelo pensamento, porquanto só a unidade do juízo garante a unidade do objeto.

"Para o pensamento", diz Cohen, "só pode valer como dado aquilo que ele mesmo está em condições de descobrir” (Id., 1977, p. 36). Porque "o ser não repousa em si mesmo; pelo contrário, é o pensamento que o faz surgir" (Ibid., p. 31). O pensamento encontra-se, pois, na origem. Ele é o fundamento. E não se trata aqui de um idealismo de tipo hegeliano, em que o pensamento e o ser se identifiquem. Para Cohen, a lógica da origem não é de modo algum a lógica do ser, mas tão só a lógica da sua validade, a lógica, como ele próprio afirma, "da consciência pura" (Ibid., p. 12). Só esta permitirá evitar totalmente as ambiguidades em que estão mergulhadas a psicologia e a antropologia, e de que as formas a priori da sensibilidade e as categorias do entendimento, segundo Cohen, estariam ainda eivadas na obra de Kant. Daí que, para aplicar à ética os pressupostos desta "lógica pura", à luz da qual só a pura forma aparece como algo de objetivo, será necessário afastar conceitos como, por exemplo, o de Gemeinschaft, a comunidade que Ferdinand Tönnies teorizara, já definida por uma série de determinações culturais, e substituí-lo pelo conceito de Allheit, a simples totalidade, de modo a poder pensar não só a ética, como o direito, sem a interferência de quaisquer conteúdos, naturalistas ou outros³

3 Sobre Hermann Cohen, cfr. Poma, 1988; Cammarota, 2002; Münster 2005; AA. VV. Herman's Cohen Critical Idealism (Amsterdam Studies in Critical Philosophy), Springer Verlag, 2005; Nordmann, 2007; Edel, 2010; AA. VV. Hermann Cohen. L'idealisme critique aux prises avec le matérialisme, Revue de Métaphisique et de Morale, n. 1, jan. 2011. 
Hermann Cohen é, pois, sem margem para dúvidas, o autor para cuja obra, em última instância, remetem os fundamentos e a arquitetura da Teoria Pura do Direito. Cohen, porém, associa Espinosa ao panteísmo e ao romantismo de Jacobi, que são efetivamente o oposto do ideal de conhecimento objetivo que o positivismo da Escola de Marburg exalta, como condição sine qua non de sobrevivência da filosofia e do seu reconhecimento como ciência. Lendo Espinosa como o lê Cohen, seria impossível a Kelsen rever-se nos seus pressupostos e aperceber-se de quanto a sua própria filosofia do direito pode ler-se como um eco, decerto esbatido, mas ainda assim claramente perceptível, da filosofia do autor da Ética. É, no entanto, esse mesmo eco, paradoxalmente, que o levará a afirmar a autonomia da ciência do direito quer face à religião, quer face à própria ética, e a realizar, com a Teoria Pura do Direito, a tentativa mais radical alguma vez ensaiada, no interior do positivismo lógico, para pensar as questões jurídicas.

Não irei aqui demorar-me na exposição minuciosa dos conceitos e argumentos de Kelsen, entre outros motivos, porque alguns deles - por vezes, os principais - foram sendo objeto de reformulações sucessivas, nem sempre bem-sucedidas em termos de clarificação e coerência, ao longo da vida do autor. Vou antes limitar-me a enunciar dois aspetos da sua doutrina que sobressaem como especialmente relevantes quando projetados, retrospetivamente, sobre a obra de Espinosa: o primeiro é a coincidência dos conceitos de 'direito' e de 'Estado', a qual arrasta consigo a coincidência da legitimidade e da legalidade, e bem assim a crítica das doutrinas clássicas do jusnaturalismo e da soberania, que poderá ler-se, mutatis mutandis, tanto em Kelsen como em Espinosa; o segundo é o conceito de 'norma fundamental', que aparece como chave da ciência do direito de Kelsen e que, em meu entender, poderá trazer alguma luz à tão discutida expressão de Espinosa una veluti mente. 
Comecemos pelo Estado. Kelsen rejeita a concepção trivial do Estado enquanto comunidade de vontades, autónoma e prévia à ordem jurídica, seja na sua versão metafísica e ética, seja na versão sociológica:

Se a teoria do Estado não quiser ir além dos dados da experiência e degenerar em especulação metafísica, a 'vontade coletiva' ou 'consciência coletiva' não pode ser a vontade ou a consciência de um ser diferente dos indivíduos humanos que pertencem ao Estado. O termo vontade coletiva, ou consciência coletiva, só pode significar que vários indivíduos querem, sentem ou pensam da mesma maneira e estão unidos pela consciência desta comum vontade, sentimento e pensamento (Kelsen, 2006, p. 184).

Acontece que uma tal unidade só existe realmente nos momentos em que o grupo, por natureza disperso e dividido, se põe de facto de acordo sobre algo de concreto. Pressupor que todos os cidadãos de um Estado podem pensar, sentir e querer constantemente do mesmo modo é, obviamente, "uma ficção política" (Ibid., p. 185), mesmo que essa ficção apareça como um plano superior de conciliação da conflitualidade natural das vontades empiricamente dadas, como é o plano da eticidade hegeliana. A sociologia argumentará que essa união resulta do fato de existir quem a produza e mantenha, isto é, do fato de haver quem dá ordens e quem obedece, durante o tempo necessário à sua consolidação. No entanto, argumenta Kelsen, na sociedade há muitas ordens que são acatadas e que não se associam ao Estado. Por exemplo, a ordem que dá um assaltante à sua vítima, para que lhe entregue os seus pertences. É certo que uma ordem dada em nome do Estado, assim como a dominação permanente exercida por este, reclamam para si um estatuto diferente e uma legitimidade, que tanto os que mandam como os que obedecem alegadamente reconhecem. O que significa, porém, ordenar ou 
agir em nome do Estado? Como imputar ao Estado decisões e ações, se, na realidade, estas são da responsabilidade indivíduos isolados, ou de pequenos grupos que detêm o poder? As doutrinas políticas, pelo menos na modernidade, explicam semelhante sinédoque invocando o dispositivo da 'representação': para efeitos de decisão sobre assuntos públicos, os governantes tomam-se pelo todo do País a que pertencem. Todavia, recorrer ao conceito de representação é, para Kelsen, cair novamente no pântano da metafísica, e ele recusa, como positivista que é, os avatares do transcendente que se lhe afiguram presentes numa tal justificação do poder. Pior ainda, vê na representação, recorrendo à inspiração de Freud, uma reminiscência das festividades primitivas, descritas em Totem e Tabu, durante as quais os filhos afivelavam no rosto a máscara do pai assassinado e dançavam alucinados em torno da sepultura, na convicção de que através desse ritual a força e o poder do totem incarnariam, por um instante que fosse, no corpo de cada um deles. Agir em nome do Estado, segundo Kelsen, não pode significar na ciência do direito senão estar de acordo com uma determinada ordem jurídica, isto é, agir por força de uma norma que, em sendo legítima, legitima o ato. E como se sabe que a norma é legítima? Porque existe uma norma anterior a essa, que a contém e qualifica o agente para agir dessa maneira. Assim,

Uma ação é um ato do Estado, se for a execução de uma ordem jurídica. (...) Mas os atos do Estado não são apenas as ações humanas pelas quais a ordem jurídica é executada, são também as ações humanas pelas quais a ordem jurídica é criada. São atos executivos e atos legislativos. Imputar uma ação humana ao Estado, como se fosse a uma pessoa invisível, é relacionar uma ação humana, enquanto ação de um órgão do Estado, à unidade da ordem que estipula tal ação. $\mathrm{O}$ Estado como pessoa não é senão a personificação desta unidade (Ibid., p. 192).

O Estado, por conseguinte, é um sistema de atos prescritivos ou derivados de prescrições, sistema esse que não conhece 
exterioridade a si mesmo: uma prescrição, ao contrário de uma proposição, não é verdadeira nem falsa: é válida ou não é válida. E é válida se traduzir uma ordem de uma vontade qualificada para a prescrever. O Estado não só não é rigorosamente nada para além dessa unidade sistemática, como também não se cruza com nenhuma outra ordem que possa existir no seu exterior e que necessariamente lhe é paralela, como por exemplo a ordem moral. Existe, com certeza, a moral, e os indivíduos movem-se por ou contra ela, por ou contra os valores em que ela se traduz. Contudo, um valor que pertence à ordem moral não é passível de objetividade e, por isso mesmo, não pode constituir um dado para a ciência do direito. A menos que ele seja transposto para uma ordem jurídica. Aí, porém, a sua validade dependerá da qualificação da pessoa ou órgão que a integrou como norma juridicamente válida. Com efeito, ela só ganha ‘força de direito’ no momento em que for dita de direito, mediante uma jurisdictio.

A uma primeira análise, semelhante identificação do poder e do direito dir-se-ia remeter para Hobbes e para a sua sigla que diz ser a autoridade e não a verdade que faz a lei ${ }^{4}$ Como é sabido, na concepção do autor inglês é o poder soberano que estabelece o que é justo e o que é injusto, suspendendo qualquer ordem de valores antecedente e superior à instituição da justiça por ele próprio. Visto, porém, numa perspectiva positivista, o sistema hobbesiano está assente sobre duas falhas inaceitáveis: uma falha a montante e outra a jusante.

A montante, o hobbismo está fundado naquilo que o autor

4 "Doctrinae quidem verae esse possunt; sed auctoritas non veritas facit legem" (Hobbes, 1966, p. 202). No original inglês [1651], a frase surgia em termos diferentes, embora o sentido seja o mesmo: "The interpretations of the laws of nature, in a Commonwealth, dependes not on the books of moral philosophy. The authority of writers, without the authority of the Commonwealth, makes not their opinions law, be they never so true". Uma frase análoga vem em A Dialogue between a Philosopher and a Student, of the Common Laws of England [1681]. In: W. Molesworth (1839-1845) (ed.). The English Works. Vol. VI, rep. London: Scientia Verlag Aalen, 1965, p. 5: "It is not wisdom, but authority, that makes a law". 
classifica de 'terceira lei da natureza', isto é, a obrigação que os homens têm de obedecer aos pactos que celebram uns com os outros, visto que, sem essa garantia de obediência, seriam inúteis tanto a primeira lei, que manda procurar a paz, como a segunda, que estipula a necessidade do pacto. Ora, basear a organização político-social numa obrigação ou lei moral é supor que os homens se conduzem pela razão. E como, a maior parte das vezes, não é esse o caso, o sistema incorre em utopia.

A jusante, o seu fundamento reside inteiramente na vontade do soberano, uma vez que o pacto não estabeleceu quaisquer condições ou critérios a que ele estaria sujeito quando determinasse o que é de direito. Dito por outras palavras, a multidão não constitui o poder, isto é, não lhe dá uma constituição que o condicionasse, pelo simples motivo de que, antes de existir poder político, a multidão não existe enquanto pessoa e, por conseguinte, não pode exprimir-se numa vontade comum. É verdade que, se o soberano atuar racionalmente, percebe que é também do seu interesse adequar as leis ao interesse comum da sociedade, por forma a garantir a segurança e a perenidade do Estado. Infelizmente, não existem mais garantias de o soberano se conduzir racionalmente, e saber o que lhe convém, do que existem de os cidadãos o fazerem. Estamos, por conseguinte, como Schmitt repetidamente observará, perante uma ordem jurídica cujos fundamentos transbordam para fora do sistema e não podem ser objeto de uma verdadeira ciência do direito5.

O projeto de Kelsen pretende obviar a estas duas «falhas», retirando a autonomia ontológica à soberania e ao político. Aquilo a que se chama poder resume-se, na sua teoria, a uma cadeia transitiva, horizontal e impessoal de atos de criação e execução de leis, a qual funciona como simples técnica de regulação e har-

5 Para uma análise minuciosa dos fundamentos da soberania hobbesiana, cf. Christian, 1998 , pp. 311-318. 
monização da sociedade. Nessa cadeia, há decerto lugar para a autoridade. No entanto, a autoridade do legislador não deriva de uma qualquer hipóstase da vontade comum, de uma ideia ou de um ser transcendente, fosse ele o povo ou a nação. Pelo contrário, ela deriva unicamente da inserção do seu ato numa série de procedimentos, sempre formais e nunca legitimados seja pelo eventual carisma do decisor, seja pela natureza substantiva da decisão, que alegadamente a inscreveria numa ordem superior, conforme defende o jusnaturalismo. Não existe, nesse sentido, um «bem comum», se por bem comum entendermos um padrão de medida pelo qual se avaliariam os atos jurídicos. Existe um direito que emerge sempre da relação de cada norma com outras normas, legitimando-se todas pela sua validade, a qual as distingue do não-jurídico, daquilo que não pode ser pensado nem reconhecido como válido pela ciência do direito, precisamente porque se dá à margem de todas as formas em que a simples ordem se constitui como direito. É essa a única forma concreta que assume o querer comum, ou seja, o Estado.

Se o analisarmos a partir desse seu carácter de absoluta imanência, não é difícil ver no Estado kelseniano um eco do imperium espinosano. Desde o início do $\mathrm{TP}$, a política apresenta-se como instância desligada quer da utopia, em que a natureza humana seria coagida pelos ditames do dever-ser e da razão, quer da arte de governar, em que ela estaria dependente das virtudes do príncipe e das técnicas de controlo das multidões por parte dos poderosos (Cf. TP 1/1 e 2). Nem moralismo, nem empirismo: apenas realismo. É verdade que os homens, onde quer que vivam, "não podem viver sem algum direito comum". Mas se esse direito comum, acrescenta Espinosa, estiver dependente das qualidades ou habilidades dos governantes, depressa deixará de ter algo a ver com o comum, para passar a estar capturado exclusivamente por alguns e, deste modo, avançar para a sua própria ruína:

Um Estado cuja salvação depende da palavra dada por alguém, e cujos 
assuntos só podem ser corretamente geridos se aqueles que deles tratam quiserem agir lealmente, não terá a mínima estabilidade. Ao invés, para que ele possa durar e ser estável, as coisas públicas (res publicae) devem estar ordenadas de tal maneira que aqueles que as administram, quer se conduzam pela razão, quer se conduzam pelo afeto, não possam ser induzidos a estar de má-fé ou a agir desonestamente (TP, I, 6).

Daí a importância que assume a questão da condição do imperium, ou forma do Estado. Para assegurar a sobrevivência de uma cidade, ou Estado, é preciso que esta determine qual a natureza do poder, quais as regras da decisão soberana, em vez de serem os governantes a determiná-lo. Se a compararmos com outras, onde existe menos corrupção, “isso nasce de essa cidade não providenciar o bastante pela concórdia, nem instituir os direitos com suficiente prudência" (TP,V, 2). E nem vale a pena derrubar tiranos, se não se eliminarem as causas da tirania (TP, $\mathrm{V}, 7)$. Numa palavra, o poder não pode ser pensado, à maneira hobbesiana, como se fosse uma instância exterior ao agregado, com a capacidade de determinar em absoluto a natureza do justo e do injusto, ou seja, o direito. Isto mesmo é claramente afirmado no início do capítulo VII do TP, em clara refutação da doutrina do Leviatã:

Em parte nenhuma, que eu saiba, se escolhe um monarca sem absolutamente nenhumas condições expressas. (...) Os fundamentos do Estado devem ser tidos como decretos eternos do rei, de tal maneira que os seus funcionários lhe obedecerão completamente, se, quando ele der alguma ordem que repugne aos fundamentos do Estado, se negarem a executar o que ele mandou. (TP, VII, 1 )

Existe, pois, uma desobediência virtuosa, que o autor compara à desobediência dos companheiros de Ulisses, os quais o pouparam à vertigem do canto das sereias, ao manterem-se fiéis às ordens que ele lhes dera quando pediu que o amarrassem ao 
mastro do navio, e não the dando ouvidos quando depois lhes exigia que o desamarrassem. Não é uma virtude que transcenda o direito, uma virtude que se legitimasse por força da sua qualidade intrínseca. Dito de outro modo, essa desobediência não colhe a sua legitimidade em alguma ordem exterior ao direito como seria, por exemplo, a ordem moral, ou um pragmatismo de qualquer tipo - em nome da qual se pudesse suspender a ordem legal, à semelhança do que faz o soberano schmittiano, ao decidir do Estado de excepção em nome de valores que subjetivamente rotula de superiores. A desobediência ao soberano a que Espinosa se refere neste texto encontra a sua legitimidade tão só nos chamados "decretos eternos do rei", ou fundamentos do Estado, os quais antecedem, de um ponto de vista lógico, toda a produção normativa. Só nessa medida é que se pode falar de um constrangimento ao arbítrio do monarca, porquanto as suas ordens, se não forem uma dedução dos fundamentos do Estado, são juridicamente nulas e requerem, para ser levadas à prática, o recurso à força, contra a potência da multidão.

A uma primeira leitura, seríamos levados a pensar que Espinosa, ao admitir que pode existir virtude na desobediência às normas do soberano, restabelece o jusnaturalismo tradicional e repõe a assimetria entre legitimidade e legalidade, que Hobbes pretendera eliminar. Dificilmente, porém, semelhante retorno ao jusnaturalismo se compreenderia num autor que, pelo menos nesta matéria, se revê no capítulo XV do Príncipe, onde Maquiavel se insurge contra aqueles que esquecem na política o que os homens são realmente, para olhar apenas ao que eles deveriam ser. Torna-se, por isso, necessário averiguar a natureza dos mencionados "fundamentos do Estado", que surgem no TP como se fossem uma instância normativa superior ao próprio monarca, mas que a metafísica do autor impede que se confundam com princípios transcendentes, da mesma forma que o seu realismo impede que se tomem por valores éticos. Já vimos que, de alguma forma, eles delimitam o campo de ação dos governantes, deixan- 
do antever aquilo que a Revolução Francesa viria depois a consagrar como a constituição do Estado, se bem que não se traduzam num quadro normativo positivo ${ }^{6}$. Ao operarem uma tal delimitação e constituírem, por assim dizer, o imperium, eles representam de fato um travão à hipótese, sempre presente, de o poder atuar segundo o arbítrio pessoal, contra aquilo que a razão recomenda e que melhor preservaria o Estado. Nessa medida, o imperii status será tanto mais adequado quanto maior for o grau de impessoalidade a que ele induz o poder soberano e a consequente redução das hipóteses de absurdo. Em resumo, o Estado será tanto melhor quanto melhor for a arquitetura jurídica sobre a qual está assente e quanto menos depender da qualidade ou do engenho individual de cada um dos seus governantes.

Cabe, todavia, perguntar: em que princípios está assente essa arquitetura, ou, melhor dizendo, em que é que os fundamentos do Estado se fundamentam? De onde lhes vem esse tipo de supremacia que possuem sobre a vontade do monarca e dos governantes? Voltaremos a esse aspeto no ponto seguinte. Antes, porém, convém aqui recordar aquilo que é o essencial da concepção jurídica de Espinosa, a saber, a equivalência entre o direito comum e a potência da multidão (TP, III, 9). O direito comum é resultado

6 Alguns tradutores não hesitam em traduzir a expressão espinosana "optimo imperii statu" (TP, V , 1) por "a melhor constituição do Estado", o que é um manifesto anacronismo, tendo em conta que o significado de constituição, generalizado no sec. XVIII, como conjunto de normas positivas que estão na base da pirâmide de todo o direito positivo, não aparece em Espinosa: cf. as traduções de Lelia Pezillo (Roma-Bari, Laterza, 1995) e de Atilano Dominguez, (Alianza Editorial, 2004). Outras vezes, a expressão é traduzida por «o melhor regime», o que também não parece adequado, se atendermos ao contexto e, bem assim, ao método simplesmente descritivo que Espinosa utiliza para apresentar os três regimes tradicionais: cf. as traduções de Charles Ramond (Paris, PUF, 2005), e de Émile Saisset (Paris, Le Livre de Poche, 2002), recentemente revista por Laurent Bove, que substitui «constitution» por «condition», sem dúvida mais fiel a status e, porventura, ainda mais próximo da linguagem dos nossos dias do que o termo «situação», pelo qual nós traduzimos (São Paulo, Martins Fontes, 2009). No mesmo sentido, Samuel Shirley traduz por "the best way" (Indianopolis, Hackett Publishing Company, 2000) e Omero Proietti, por "condizione" (Opere, Milano, Mondadori, 2007), enquanto Wolfgang Bartuschat opta por «Form» (Politischer Traktat, Hamburg, Felix Meiner Verlag, 2010). 
da junção de vários direitos individuais, sendo que o direito de cada um se estende até onde se estender a sua potência, que o mesmo é dizer, a sua capacidade de garantir a si mesmo a sobrevivência e o bem-estar, e de se libertar da sujeição a outros, realizando-se como esse sui júris: ser de direito próprio. Se a junção se fizesse em termos estritamente racionais, o direito comum seria igual à soma aritmética das potências associadas. Mas a junção faz-se tanto por motivos racionais quanto por força dos afetos, pelo que o grupo está interiormente atravessado por dinâmicas que ora reforçam a sua potência e, por conseguinte, o seu direito, ora o reduzem. Pode mesmo perguntar-se como é possível uma junção com alguma estabilidade, tendo em conta a inconstância afetiva dos indivíduos que formam o grupo e que oscilam permanentemente ao sabor de afetos contraditórios. Hobbes, como é sabido, considerava ser impossível que tal junção, por si só, formasse uma potência comum. Para se chegar a uma potência e a um direito comum, considera o autor do Leviathan, é necessário desfazer primeiro todos os esboços de agregação natural, que são outros tantos focos de guerra, e reduzir cada indivíduo à sua singularidade7. Só assim eles poderão anuir a um soberano, assente na autoridade hipoteticamente pactuada pelos súbditos, que confere à multidão a unidade artificial de uma vontade comum, de um direito e de uma commonwealth. Mas para Espinosa, a questão da génese do Estado é supérflua, porquanto "os homens desejam por natureza o Estado civil, não podendo acontecer que alguma vez eles o dissolvam por completo" (TP, VI, 1). A hipótese do Estado de natureza, que equivaleria à ausência absoluta de um direito comum, é contra toda a experiência, da mesma forma que a hipótese simétrica - um Estado civil em que o direito fosse a expressão integral do preceituado pela razão - não passa de uma quimera.

7 Este aspeto é particularmente realçado em Roberto Esposito, Communitas. Origine e destino della communità. Torino: Einaudi, 2006, cap. I. 
Em consequência, a base do direito comum terá de procurar-se, antes de mais, naquilo a que Espinosa chama de "afetos comuns".

$\mathrm{Na}$ verdade, os homens unem os seus esforços, seja por medo, por ambição ou por vontade de vingança, e dessa união, alimentada pela imitação dos afetos, nascem costumes, direitos consuetudinários, linguagens e símbolos partilhados, numa palavra, instituições. As instituições contrariam a sempre fluida movimentação dos afetos. Elas são uma espécie de coágulos, 'precipitados', como se diz em Química, no seio da potência da multidão. Através delas, estabilizam-se afetos comuns e introduz-se uma ordem na potência coletiva, na medida em que as associações resultantes da imitação dos afetos ganham formas consistentes, as quais normalizam e tornam menos imprevisível o agir de governantes e de governados. Sendo, porém, formadas na argamassa dos afetos, as instituições podem igualmente cristalizar 'paixões tristes' e, como tal, reduzir a potência individual, em vez de contribuir para a liberdade de cada um, que é a razão de ser da república. Ao constituírem uma segunda natureza, as instituições podem, de fato, estabilizar a submissão e a própria alienação, produzindo fenómenos que contrariam a racionalidade, como aquele que Rousseau virá a denunciar como "os escravos por natureza" e que são homens que já não se identificam a si mesmos como seres livres. Pelo contrário, quando nas instituições se cristalizam 'paixões alegres', elas preservam a «memória da liberdade», como diz Maquiavel, e não deixam o povo "repousar", enquanto estiver submetido pela força a alguém que o tenha conquistado (Maquiavel, 2008, p. 132).

Além disso, as instituições, embora contrariem, não eliminam a espontaneidade individual, essa reserva de interioridade que está fora do alcance do poder e das suas normas, conforme Espinosa refere, no início do capítulo XVII do Tratado teológico político (doravante TTP). Embora assente no que é comum, o Estado não apaga a dissidência e o eventual conflito, pelo que a potência da multidão, independentemente do seu grau, é sempre uma soma algébrica e pode apresentar diversas configurações. 
Tanto pode convergir para um poder unipessoal, como dispersar-se por um número maior ou menor de indivíduos e instituições, ou até ser propriedade de todos os que forem cidadãos. Em qualquer caso, a capacidade de decisão e o mando ficarão nas mãos de um grupo distinto daquele a quem cabe a obediência. E como cada um desses grupos tenderá a elevar ao máximo a respetiva potência, está criada a situação bem caracterizada por Maquiavel: os que mandam tendem a mandar cada vez mais, isto é, a capturar em proveito próprio toda a potência comum, e os que obedecem tendem a libertar-se, tanto quanto podem, do mando alheio.

Semelhante tensão não acaba nunca, porque ela é intrínseca à potência da multidão. Por um lado, esta apresenta-se como potestas, ou seja, como governo - monárquico, aristocrático ou democrático; por outro, ela permanece mais ou menos residualmente nos indivíduos, nos costumes e nos grupos, seja a título de opinião e juízo crítico, seja mesmo de possível resistência, determinando e condicionando por isso o sentido das decisões da mesma potestas (sobre este circuito, na realidade elíptico, da potência da multidão entre potestas e resistência, Cf. Tosel, 2008, pp. 257-260). Contra a resistência da multidão, o poder procurará iludi-la ou dominá-la pela força; contra o arbítrio do poder e a sua vontade de aumentar a potência capturada, à custa da redução da potência individual de cada súbdito, estes, pela capacidade que têm de se indignarem, tornar-se-ão temidos a prazo mais ou menos curto. É na medida em que mete medo aos que mandam que a multidão consegue "alguma liberdade para si, a qual reivindica e mantém, se não expressamente na lei, ao menos tacitamente" (TP, VII, 4). E é também por esse motivo que tanto o governo monárquico, como o aristocrático, nunca são «totalmente absolutos». Em qualquer deles, existe uma assimetria vertical entre o estatuto do poder e o estatuto dos súbditos, fruto do desdobramento da potência da multidão em potestas legisladora e resistência dos que lhe estão sujeitos, o qual se representa na imaginação como desajustamento entre legalidade e legitimidade. Provêm daqui as 
sucessivas deslocações do ponto de equilíbrio da potência da multidão. É que tanto os governantes como os governados se movem por afetos e interesses. E para resistir aos efeitos potencialmente destrutivos da tensão que assim se estabelece, é preciso que os fundamentos do Estado estejam o mais próximo da razão, não de uma razão substantiva e abstraída da realidade, mas de uma razão-proporção, de uma combinatória de normas elementares que, a partir da situação concreta do Estado - por exemplo, a sua dimensão, demografia, riqueza, etc. - dêem lugar a uma ordem jurídica tal, que faça com que os interesses dos governantes passem pela satisfação dos interesses dos governados, numa espécie de homenagem que o vício presta à virtude: "é necessário lançar fundamentos firmes (...) dos quais resulte a segurança do monarca e a paz da multidão, de tal modo que o monarca esteja tanto mais sob jurisdição de si próprio quanto mais atender à salvação da multidão" (TP, VI, 8). E quem diz o monarca, diz as assembleias em quem a forma do Estado deposita a capacidade de deliberar.

A democracia, contudo, é um Estado totalmente absoluto. Nele, a ordem jurídica incorpora, sem resto, a potência da multidão, pelo que aí a legalidade e a legitimidade se representam em total coincidência, exatamente como sucede com a ordem normativa de Kelsen. O modo que assumiria, segundo o entendimento de Espinosa, a produção legislativa no Estado democrático é, sem dúvida, uma incógnita, além do mais pelo facto de o TP ter ficado inacabado. Pode até presumir-se que não haja solução para o problema (Cf. Balibar, 1985, p. 90; Matheron, 1994, pp. 153-165 [esp. p. 64]); ou que a democracia espinosana, paradoxalmente, só seria realizável na ausência de toda e qualquer forma de Estado (Cf. Montag, 1999, pp. 84-85); ou, ainda, que à luz da razão o seu fundamento não é equacionável senão de modo incompleto, e que, em consequência, mais do que o ser da democracia, importará o fazer democracia, mais do que a definição, porventura impossível, da sua essência, importará o processo da sua dinamização. Existe, contudo, uma dificuldade. É que um processo não é um 
Estado, e Espinosa refere a democracia como sendo "o Estado totalmente absoluto".

Sendo a democracia um tipo de Estado, ela possuirá também os seus fundamentos. Mas, ao contrário do que pretendem algumas interpretações, segundo as quais seria possível o levantamento das fundações da democracia a partir apenas da obra espinosana, pelo que o inacabamento do TP seria irrelevante, é necessário prestar atenção ao que Espinosa diz no capítulo IV desse tratado: "se a cidade não estivesse adstrita a nenhumas leis ou regras, sem as quais a cidade não seria cidade, então deveria ser encarada, não como coisa natural, mas como quimera" (TP, IV, 4). Ora, as regras fundamentais de uma cidade não são princípios universais da razão, mas princípios estruturantes dos afetos que são comuns aos seus habitantes. Imaginar um direito comum em abstrato, uma justiça transcendente à cidade, seria recair na ilusão de uma legitimidade no exterior da legalidade, a qual, na democracia espinosana como na ciência do direito de Kelsen ${ }^{8}$, equivale a uma efabulação.

Teremos, então, de concluir que há uma ambiguidade intrínseca ao próprio Estado democrático? Em termos jurídicos, não existindo no seu exterior nenhum resto de potência que o condicione ou atemorize, um direito comum democrático equivale a uma potência sem limites, absoluta, portanto. A verdade é que, em termos ontológicos, esse direito comum defronta-se com a natureza da própria multidão, na qual se registam afetos individuais ou de grupo que tendem a prevalecer sobre os afetos comuns. Por definição, a multidão é refratária a uma unidade como aquela que o soberano hobbesiano representa, ou como a vontade geral de Rousseau, e preserva a diversidade dos 'engenhos' individu-

8 Hayek critica Kelsen, precisamente por este ignorar que "as regras da justa conduta podem conduzir à formação de uma ordem espontânea", e conclui que "o positivismo jurídico tentou, por esta razão, apagar a distinção entre as regras da justa conduta e as regras de organização, e pretendeu (...) que a concepção da justiça não tem nada a ver com a definição do que é a lei” (Hayek, 1982, p. 55). 
ais, bem como a singularidade, que se define como um processo permanente de resistência a toda a jurisdição alheia. Conforme Negri pretende,

Mesmo se ela é inassimilável, a multitudo é, no entanto, um sujeito jurídico, imputação necessária do processo social, hipótese de unidade e de construção política (TP, III, 7). Mas, ao mesmo tempo, a multitudo permanece um conjunto inassimilável de singularidades. Tal é o paradoxo crucial - aquele que se estabelece entre natureza física, múltipla, inassimilável da multitudo e a sua natureza subjetiva, jurídica, criadora do direito e da constituição. Esta relação é insolúvel (Negri, 1994, p. 55).

A relação é insolúvel, acrescentaríamos nós, decerto ao arrepio de Negri, porque não há política nem direito sem a pressuposição de uma unidade, e a multidão é ao mesmo tempo unidade e o seu oposto. Mas é uma insolubilidade que faz parte da própria natureza da cidade. E a natureza da cidade, pensando agora como Kelsen, dá-se tanto no plano do direito como no plano da sociologia. São planos paralelos, é certo. Mas a natureza que em ambos se dá é a mesma.

\section{III}

Resta, como dissemos, um problema, tanto para Espinosa como para Kelsen. A saber: qual é o fundamento dos fundamentos da cidade, ou da sua constituição? Melhor dizendo, o que é que faz a cidade, ou Estado, ser uma cidade, com uma identidade própria, e não um conjunto avulso de regras, como tudo indicaria, tendo em conta a sua natureza empírica e a necessidade de as suas leis regularem a passionalidade? Vimos como a soberania de tipo hobbesiano é recusada, em virtude de ela fazer assentar o corpo jurídico-político na passionalidade de uma pessoa exterior à multidão. Contra tal solução, Espinosa convoca, não a transcendência de uma justiça definida no plano da racionalidade em abstrato, mas o estabelecimento de um sistema de regras e 
direitos que leve a potência dos conatus singulares a conjugar-se em afetos comuns e a cristalizar-se em instituições, mediante as quais a obediência vai de par com o acréscimo da liberdade individual. No entanto, esta rasura da transcendência, esta descida do corpo soberano à terra comum da imanência, onde se cruzam e entrelaçam os afetos, não esgota o problema do fundamento da soberania. Porque, seja unipessoal ou multitudinária, relativa ou absoluta, a soberania, enquanto poder de ditar o que outrem pode ou não pode fazer, pressupõe um fundamento, uma razão que a justifique à luz da razão. Poderá sempre dizer-se que esse fundamento é empírico e não reside senão na força que esteve na sua origem. Nesse caso, porém, abandonar-se-á a questão do direito, sendo as normas colocadas ao nível dos factos e o problema do fundamento reduzido à história da fundação9. Pensar um sistema de regras como direito comum implica perguntar pela fonte desse direito. E não basta afirmar que em Espinosa essa fonte é a potência da multidão. Com efeito, é impossível afirmar que a multidão é fonte da lei pela qual ela mesma se rege, sem pressupor uma distinção conceptual entre a multidão que é regida e a multidão que dá as regras, mesmo se esta última só logicamente é anterior e distinta. Rousseau enuncia claramente o problema, no capítulo V do Livro I do Contrato Social, quando se interroga como é que um povo se constitui a si mesmo como povo, respondendo que é necessário pressupor uma unanimidade logicamente anterior, mediante a qual todos consentem e legitimam as regras subsequentes, a começar pela regra que consagra as decisões da maioria como vontade comum.

Imaginar que o realismo de Espinosa ignora o problema seria, no mínimo, apressado. Basta folhear o TTP para que, nos títulos dos capítulos XIV, XV e XVI, respetivamente, deparemos com

9 Utilizamos neste passo a terminologia de Fernando Gil, que reformula o problema em termos radicalmente originais (Cf. Gil, 2000, passim). 
as seguintes expressões: "Quais os fundamentos da fé"; "Por que motivo estamos persuadidos da autoridade da Sagrada Escritura"; "Dos fundamentos da República". Além de uma tal sequência, já de si, ser relevante, em particular pela forma como transita da autoridade religiosa para autoridade civil, é igualmente relevante que a questão abordada nos três capítulos seja sempre a mesma, a saber, a questão da obediência. No capítulo XIV, o autor conclui que "a fé não requer tanto dogmas verdadeiros como dogmas piedosos, isto é, que movem o ânimo à obediência, embora na maioria deles não haja nem sombra de verdade" (Espinosa, 2004, p. 310). No capítulo XV, afirma que o dogma principal da teologia é que "os homens se salvam apenas pela obediência", e que esse dogma é "impossível de demonstrar pela razão", pelo que “a revelação foi extremamente necessária”, sendo que "nós podemos usar o juízo para abraçarmos, pelo menos com uma certeza moral, aquilo que já foi revelado" (Ibid., p. 320). Por fim, no capítulo $\mathrm{XVI}$, enuncia os fundamentos da democracia em termos mais ou menos hobbesianos, deduzidos da hipótese do contrato e do consequente "arbítrio legítimo" dos poderes soberanos. Nem sequer o vulgarmente chamado "direito divino" constrange o soberano a obedecer-lhe, visto depender de uma revelação, e não integrar, por isso, nem o direito civil, que depende inteiramente dele próprio, nem o direito natural, que depende de "um eterno decreto de Deus, que para nós é desconhecido” (Ibid., p. 337). Em resumo, a autoridade funda-se em certezas morais, como são todas as certezas relativas à vida prática e à utilidade comum. Mais ainda, numa antecipação do que será a doutrina do TP e a rutura definitiva com o hobbismo, Espinosa diz e repete no TTP que essa autoridade só mantém o direito à obediência enquanto mantiver a potência para se fazer obedecer (Cf. Ibid., pp. 329-330). Ou seja, a política não interrompe o fluxo da natureza, é antes o seu prolongamento, como reza a carta 50.

E, no entanto, Espinosa fala de estados, descreve com mais ou menos minúcia as diferentes configurações da potência, a qual 
se efetiva como direito comum de uma multidão que se conduz una veluti mente, quer dizer, como que por uma só mente. Uma interpretação idealista poderia ser tentada a ver aqui uma subjetivação da multidão, de tal modo que esta, apresentando-se como infinidade de focos de resistência à captura da potestas por interesses singulares, conseguiria determinar o direito comum de forma verdadeiramente democrática e produzir assim a concórdia e a paz. Todavia, a natureza humana jamais abandona a passionalidade que constitui cada um dos seus modos. Além disso, Espinosa não reserva à democracia o qualificativo de "multidão que se conduz como que por uma só mente”. O direito do Estado é sempre direito de natureza que "se determina pela potência, não já de cada um, mas da multidão, que é conduzida como que por uma só mente" (TP, III, 2). A questão, portanto, é como pensar essa unidade que subsume não apenas a conflitualidade natural das paixões, mas também a divisão produzida, por cada um dos atos normativos, entre aqueles a quem a norma convém e aqueles que lhe estão simplesmente obrigados? Numa palavra, qual o estatuto dessa mente una para a qual remete sempre, em última instância, o processo decisório?

Enunciar desta forma a questão do fundamento do direito em Espinosa é aproximá-la, deliberadamente, dos termos em que a formula Kelsen. Como é sabido, a validade de uma norma ou de um ato normativo, segundo Kelsen, depende sempre de uma norma anterior, e assim sucessivamente, num processo regressivo - da norma fundada à norma fundante - que remonta à Constituição do Estado, a qual, por sua vez, não é senão um conjunto de normas positivas. Daí o conhecido problema do positivismo jurídico: se a validade das normas assenta em normas, e assim por diante até às normas constitucionais, em que é que assenta a legitimidade das normas constitucionais? Tal como acontece em Espinosa, Kelsen exclui também o recurso a todo o tipo de transcendência, assumindo um relativismo, profundamente democrático, que deixa o direito a pairar por sobre a rigorosa ausência de 
verdade (Cf. Marramao, 1985, pp. 209-210). A Constituição não emana, por conseguinte, de nenhuma instância superior, religiosa ou ética, que selasse a sua validade: tanto a ideia de Deus e seus mandamentos, como a ideia de justiça, estão interditas na ciência do direito, por manifesta falta de objetividade. Tão-pouco a chamada vontade popular, ou interesse geral, que na modernidade assume o estatuto de vontade soberana e se assemelha a uma espécie de 'ego ampliado' escapa às malhas da subjetividade e da ideologia, que a tornam inapta em sede de ciência do direito. Todas as normas - vale dizer, o Estado, a sua lei e a sua atividade - são válidas e, portanto, legítimas, se forem conformes à legalidade, isto é, às normas anteriores que expressamente declaram a sua legalidade. E, no entanto, as normas constitucionais são prescritivas por definição. Prescrições de quem? A partir de que princípios? Histórica e sociologicamente, a resposta a esta questão remete, pelo menos desde Sieyes e a Revolução Francesa, para o poder constituinte do povo, ou para uma primeira constituição. Porém, o povo, enquanto sujeito de uma vontade legisladora, é aos olhos de Kelsen tão pouco objetivo como qualquer outra entidade metafísica. E quanto a uma primeira constituição, ela levanta exatamente o mesmo problema, porquanto esbarramos sempre numa fonte normativa que se toma como autopoiética e, por isso, a sua validade é sem fundamento. Confrontado com este tipo de questões, Kelsen reconhece a necessidade de recorrer a uma Grundnorm, ou basic norm. Todavia, quer o significado, quer a aplicação deste conceito revelam-se problemáticos, como se demonstra, inclusivamente, pelas oscilações sucessivas a que dá azo no decorrer da obra do próprio autor.

Embora não seja aqui o lugar para uma análise exaustiva da Grundnorm e das suas diversas formulações por Kelsen, deve no entanto sublinhar-se que ela se apresenta e é requerida pelo sistema como um simples operador epistemológico, sem correspondência no exterior da ordem jurídica, à qual é imanente (Cfr. Gustafsson, 2007, p. 86). Conforme observou Simone Goyard-Fabre, 
ela é trans-positiva, porquanto não tem conteúdo nem expressão em nenhuma norma positiva, além de transcendental, mas não é nem metafísica nem transcendente (Goyard-Fabre, 1991, p. 123). Kelsen atribui-lhe, por isso, na Teoria Pura do Direito, o estatuto de uma hipótese «lógico-transcendental» que terá de se pressupor, deixando clara, uma vez mais, a influência neo-kantiana de Hermann Cohen:

Assim como Kant pergunta "como é possível uma interpretação, alheia a toda a metafísica, dos factos dados aos nossos sentidos nas leis naturais formuladas pelas ciências da natureza?", a Teoria Pura do Direito pergunta: "como é possível uma interpretação, não reconduzível a autoridades meta-jurídicas como Deus ou a natureza, do sentido subjetivo de certos fatos como um sistema de normas jurídicas objetivamente válidas, descritíveis em proposições jurídicas?”. A resposta epistemológica (teorético-gnosiológica) da Teoria Pura do Direito é: sob a condição de pressupormos a norma fundamental segundo a qual devemos conduzir-nos como a Constituição prescreve, quer dizer, de harmonia com as prescrições do autor da Constituição. (Kelsen, 2008, p. 225)

A norma fundamental é, pois, vazia. Ela não traduz nenhuma vontade subjetiva que se objetivasse como direito, enquanto norma positiva, e surge apenas como exigência da mente, com vista à possibilidade de se conhecer de modo científico um conjunto de determinações subjetivas - ordens dadas por alguém em concreto - que é assumido como ordem jurídica num determinado território. Tal como as categorias do entendimento na Crítica da Razão Pura, que não determinam o conteúdo das leis da natureza, não obstante serem condição de possibilidade para o seu conhecimento, a Grundnorm não determina o conteúdo das normas jurídicas. No entanto, sem ela, a validade ou objetividade destas ficaria irremediavelmente comprometida, e toda a ciência do direito ruiria por ausência de fundamento, assim como pela consequente ausência de um limite que a tornasse impermeável 
a figurações subjetivas do justo. É, pois, a norma fundamental que funda a Constituição, ao estatuir que só é legal aquilo que estiver de acordo com a Constituição.

Poderá perguntar-se - e Kelsen perguntar-se-á durante mais de meio século - em que medida a Grundnorm é realmente uma norma, quando ela não só não provém de nenhum ato de vontade, como, sobretudo, a sua validade não pode basear-se em nenhuma norma superior, sendo portanto contraditória a sua natureza e hipotético o seu estatuto: se, e somente se, pressupusermos que ela é válida, a 'pirâmide' de normas em cujo topo ela se encontra também o será. Semelhante dificuldade levará Kelsen a vacilar quanto ao estatuto da norma fundamental, que na Teoria Pura do Direito surge como «hipótese lógico-transcendental», mas que em outros escritos, quer anteriores, quer posteriores, em particular na Allgemeine Theorie der Normen, de publicação já póstuma, é interpretada como "ficção heurística", uma designação de Kant que Hans Vaihinger comenta e, de certo modo, explora em Die Philosophie des Als-Ob. É, com efeito, na obra de Kant que o termo 'hipótese' aparece reservado aos casos em que a imaginação conjetura, ou opina, com base na possibilidade do objeto sobre o qual conjetura: "A opinião, para não ser sem fundamento, deve estar ligada, como princípio de explicação, ao que é realmente dado e portanto certo, e neste caso chama-se hipótese". Em contrapartida, os conceitos da razão, dado que "não têm, evidentemente, objeto algum em qualquer experiência" - vide a ideia de alma enquanto substância simples, ou a ideia de Deus -, "são pensados de modo meramente problemático, para fundar em relação a eles (como ficções heurísticas) princípios reguladores do uso sistemático do entendimento no campo da experiência. Se sairmos desse campo, são meros seres de razão, cuja possibilidade não é demonstrável, e que não podem também, por hipótese, ser postos como fundamento da explicação de fenómenos reais" (Kant, 1994, pp. 615-616).

A distinção kantiana entre as 'ficções heurísticas' da razão - 
simples ideias reguladoras, que não possibilitam nenhum conhecimento efetivo - e as 'hipóteses' com que trabalha a ciência é especialmente comentada por Vaihinger no capítulo intitulado "O que é fundamental nas obras maiores de Kant" 1o (Vaihinger, 2008, pp. 239-256), onde Kelsen explicitamente se inspira, ao afirmar na Teoria das Normas:

O fim do pensamento da norma fundamental é o fundamento das normas que constituem uma ordem moral ou jurídica positiva (...). Esse fim não pode ser atingido senão por via de uma ficção. É por isso que convém notar que a norma fundamental, no sentido da 'filosofia do como se' de Vaihinger, não é uma hipótese - como eu próprio algumas vezes a caracterizei -, mas uma ficção que se distingue da hipótese pelo facto de ser, ou dever ser, acompanhada pela consciência de que a realidade não lhe é conforme. (Kelsen, 1996, p. 344)

De acordo com semelhante interpretação, a Grundnorm seria não só sem objeto - não há, na realidade, nenhuma norma que não seja consequência de uma vontade que a impõe -, como, além disso, não seria possível, na medida em que a sua definição é contraditória - não há norma que não seja consequência de outra norma. Estaríamos, por conseguinte, em face de uma 'pura ficção', no sentido que Vaihinger atribui a tal designação: "chamo 'puras ficções' ficções que estão em contradição não só com a realidade, mas também com elas próprias (por exemplo, os conceitos de 'átomo', de 'coisa em si') 11" (Vaihinger, 2008, p. 31).

Para se entender a viragem assim operada na ciência do direito, convirá ter em conta a distinção feita por Kelsen entre proposi-

10 Vaihinger comenta neste capítulo a «Disciplina da razão pura relativamente às hipóteses», uma das secções da «Doutrina do Método», na Crítica da Razão Pura.

11 Vaihinger distingue ainda as 'puras ficções' das 'semi-ficções', que seriam contraditórias apenas com a realidade, mas não em si mesmas, dando como exemplo as 'classificações artificiais'. 
ções e normas jurídicas. Uma proposição é sempre verdadeira ou falsa, e, se ela é verdadeira, também são verdadeiras as que dela se inferirem. Já uma norma, por sua vez, não é verdadeira nem falsa, é apenas válida ou não válida. Ora, na medida em que opera com proposições, a ciência do direito é sempre necessariamente descritiva, sem possibilidade de fazer juízos de valor. Diferentemente, porém, das ciências experimentais, o seu objeto não são os seres na acepção imediata, mas o dever-ser tal como este se encontra materializado nos vários ordenamentos jurídicos. Assim, de uma proposição que afirma, por exemplo, que a lei de um determinado país proíbe circular nas estradas a mais de $90 \mathrm{~km}$ por hora, podemos dizer que ela é objetivamente verdadeira ou falsa. Pelo contrário, da norma positiva que estabelece uma tal proibição não se pode afirmar que seja verdadeira, ou falsa, apenas pode afirmar-se que ela é, ou não, válida, isto é, que existe, ou não, uma norma superior, a cujos requisitos ela obedece. Reconhecer, pois, a validade de uma norma não retira objetividade à ciência do direito, porquanto esse reconhecimento não equivale a uma prescrição - a ciência não afirma que se deve obedecer à norma válida - mas tão-só a uma descrição ou verificação da existência de outra norma que lhe é superior e que garante a sua validade. Se uma pessoa deve pagar determinado imposto, não é por uma questão de justiça, como pretende o jusnaturalismo, é porque o seu rendimento atingiu um escalão para o qual a lei do orçamento de Estado prevê, nesse ano, aquela tributação. E, se perguntarmos por que é que a lei do orçamento obriga, a ciência do direito responderá que é porque outra norma, a Constituição, estipula a validade da lei do Orçamento, aprovada pelo poder competente. Só esse formalismo pode conferir objetividade à norma que manda pagar o imposto, tornando-a distinta, por um lado, da ordem que um ladrão dá à sua vítima para que lhe entregue, sob coação, os seus pertences; por outro, da norma moral que dita o dever de contribuir para a sociedade, com base no valor material dessa prescrição. Mas é também esse formalismo que retira à ordem ju- 
rídica no seu conjunto o fundamento ético que tradicionalmente lhe é atribuído, inclusive por Kant, e deixa em aberto o problema da clausura do sistema.

A solução encontrada por Kelsen apresenta, como vimos, sérias dificuldades. Com efeito, se a norma não é verdadeira nem falsa, não se pode falar de uma inferência lógica do conteúdo da norma superior para o da norma inferior, mas tão-só de uma cadeia de autoridades: a norma superior diz apenas quem, em que circunstâncias e com que grau de discricionariedade, está autorizado a determinar o conteúdo e a vigiar a aplicação da norma inferior. Assim, a ordem jurídica apresentar-se-á como sucessão hierárquica de autoridades, ao mesmo tempo que o direito remeterá para o plano da vontade, e não da razão, conforme havia antecipado Hobbes, na já aludida sentença: auctoritas, non veritas, facit legem. É daí que vem a identificação, a que retorna Kelsen na parte final da sua obra, entre a norma fundamental e uma 'ficção heurística' à maneira de Vaihinger: para evitar um regresso ad infinitum, a validade da Constituição teria de assentar na ficção de uma vontade que a postula e, deste modo, validará a cadeia sucessiva de atos normativos. Até que ponto, porém, este ‘irracionalismo’ se adequa ao positivismo jurídico de Kelsen?

Numa primeira análise, ele viria reconciliar o direito e o Estado com a sua realidade sociologicamente verificável. Com efeito, na génese de todos os grupos politicamente organizados sob uma Constituição, existiu sempre a supremacia, forçada ou consentida, de uma vontade que impôs e consolidou o seu domínio. Contudo, a ordem jurídica não se esgota no plano existencial ou histórico. Ela não se dá como simples fato, ou sucessão de fatos, sob pena de não haver distinção entre a ordem do guarda que nos manda parar e a ordem do ladrão que nos manda entregar a bolsa. O ser da ordem jurídica é, como dissemos, uma determinada espécie de dever-ser, um conjunto de valores não estabelecidos metafisicamente, mas produzidos por ela mesma, implicando o que podemos chamar uma transcendência na imanência. Ao con- 
trário, portanto, das ficções de Vaihinger, a norma fundamental não poderá dizer-se em contradição com a realidade fatual, visto ser de natureza onticamente diferente: uma norma não deixa de ser válida pelo fato de não ser eficaz, isto é, de se tornar letra morta e mais ninguém agir de acordo com ela.

Além disso, o recurso a uma ficção para resolver um problema científico sempre foi incompatível com o positivismo de Kelsen. Basta recordar a sua crítica a noções como a de Gemeinshaft, já referida, ou a de 'representação política' enquanto essência do parlamentarismo, ou ainda a de 'vontade popular', alegadamente expressa pela atividade legislativa do Parlamento (Cf. Kelsen, 2000, pp. 109-135). Noções desse género, aos olhos do autor da Teoria Pura do Direito, surgem como eivados de metafísica, senão de misticismo, sendo frequentemente apelidadas na obra como 'primitivas' e, consequentemente, inadequadas a uma verdadeira ciência do direito. Atribuir, pois, à norma fundamental o estatuto de 'ficção heurística' implica um entorse na doutrina, que é não só injustificado, como sobretudo incoerente com a formulação kelseniana do positivismo.

Estaria, ao menos, a concepção da norma fundamental como ‘ficção' em conformidade com a doutrina kantiana do método e, por conseguinte, escorada em bases críticas? Conforme diz Kant, na Crítica da Razão Pura,

Uma hipótese transcendental, na qual se utilizaria uma simples ideia da razão para explicar coisas naturais, não seria por isso explicação alguma, pois aquilo que não se compreende suficientemente por princípios empíricos conhecidos seria explicado por princípios de que nada compreende (Kant, 1994, p. 617).

Acontece, contudo, que o objeto da ciência do direito não é uma 'coisa natural'. Longe de poder compreender-se a partir de 'princípios empíricos', a arquitectura das suas proposições terá de assentar inteiramente em princípios postos pela própria ra- 
zão. Assim, a definição da Grundnorm como ficção, inspirada no pragmatismo que Vaihinger empresta à filosofia crítica de Kant, revela-se não só insuficiente para fundamentar a pirâmide das normas, como inclusive compromete a elaboração de uma verdadeira ciência do direito segundo os requisitos enunciados por Kelsen. Na verdade, o positivismo na versão kelseniana afasta-se das suas versões empiristas, frequentes na segunda metade do século XIX, ao elevar a noção de objeto científico a uma dimensão maximamente depurada, que tem por modelo as matemáticas e que, embora ainda inspirada por Kant, se revê acima de tudo no platonismo. É a versão de que Hermann Cohen se fizera eco, ao distanciar-se do que considera serem resquícios de psicologismo na Crítica da Razão Pura e afirmar radicalmente: "Que seja lícito ou possível dar ao pensamento qualquer coisa que não provém do próprio pensamento é um erro, alimentado pelo preconceito inerente à palavra 'dados"' (Cohen, 1977, p. 81).

Em coerência com uma tal versão do positivismo, a Grundnorm não parece coadunar-se com a 'ficção' de uma vontade, que à partida se sabe contraditória, mas que a ciência mobilizaria, como prolongamento do pensável e prótese da imaginação. De algum modo, o operador da unidade do sistema transformar-se-ia num análogo da hobbesiana Feigned or Articiall Person, e a unidade do Estado seria passível de uma configuração unipessoal e absoluta, em tudo contrária à objetividade da ordem jurídica e, mais ainda, ao pluralismo imprescindível em democracia. A única maneira de conceber a Grundnorm que não inviabiliza o pensamento de Kelsen é, na verdade, aquela a que ele próprio recorre na maioria das obras, em particular nas duas edições da Teoria Pura do Direito, onde a apresenta como 'hipótese transcendental'. Enquanto hipótese, se bem que não verificável e, por isso, diferente das hipóteses da ciência experimental, ela afasta a possibilidade de uma versão absoluta do 'uno', limitando-se a afirmar condicionalmente a validade da Constituição: se for suposto que os enunciados desta validam as leis que validam as res- 
tantes normas, então, a Constituição será válida. Mas dizer que a Grundnorm valida a Constituição não significa que contenha uma razão transcendente para lhe obedecer, o que seria contraditório com o seu carácter vazio, e acarretaria a diluição do positivismo em pressupostos jusnaturalistas. Sendo 'hipótese transcendental', a Grundnorm não afirma senão que a Constituição é válida se for tida por válida, isto é, se uma população a pressupõe como fundamento de validade das suas leis e demais normas. Na verdade, uma norma isolada não tem de ser eficaz para ser válida. Pode até, como vimos, dar-se o caso de ninguém a respeitar, sem que a sua validade esteja em causa. Um ordenamento jurídico, porém, se não for eficaz, não é senão um simples projeto, ou um documento do passado.

$\mathrm{Na}$ verdade, o direito projeta-se também no plano histórico, e dá-se a conhecer, entre outras, sob a forma de um 'facto social' empiricamente verificável. Um tal conhecimento é estranho à ciência do direito em sentido estrito, que tem por objeto unicamente as normas, o domínio do Sollen, ou do puro dever-ser. É, de resto, por essa mesma razão que, apesar de ser verdade que a Constituição só é válida se for eficaz, ela não é válida porque é eficaz, uma vez que, sendo uma norma ou conjunto de normas, não pode fundamentar-se num dado empírico, como seria o assentimento, explícito ou implícito, daqueles cuja obediência confirma a eficácia da ordem jurídica. Nenhum fato explicará por que motivo determinada concepção subjetiva do dever-ser adquiriu a objetividade da norma de direito. E é aí que reside a importância da Grundnorm. Diferente por natureza das restantes normas, porquanto não possui conteúdo nem é 'posta' ou positivada por uma vontade, a Grundnorm opera apenas, dado o seu carácter de 'hipótese transcendental', como pressuposto epistemológico do conhecimento científico da ordem jurídica. Não quer dizer que ela seja um antecedente, ou origem, a montante do sistema de normas positivas, como algumas interpretações tendem por vezes a apresentá-la. Em rigor, ela não antecede, ela dá-se, está presente e descobre-se em cada um dos momentos da dinâmica de pro- 
dução das normas, cujo conhecimento científico a pressupõe no plano lógico. A passagem da Constituição à Grundnorm não é de ordem genealógica, é de ordem crítica.

Se, por um lado, a norma fundamental permite expurgar a ciência do direito de toda a autoridade meta-jurídica, ou metafísica, por outro lado, ela isola-a de toda a contaminação empírica ou subjetiva, garantindo aos seus objetos a pureza epistemológica que uma ciência requer. Não há fonte de legitimidade para lá da legalidade; não há direito que não seja estabelecido pela série de procedimentos que a Constituição prevê: a ordem jurídica, que o mesmo é dizer o Estado, não pode ser senão auto-referencial e auto-positivada, porquanto se desenrola integralmente no interior do dispositivo presidido pela norma fundamental, e baseia-se no pressuposto de que são válidas as leis e normas que a Constituição autoriza a tomar como tal. É na imanência do sistema que a sua unidade se processa, não porque esta traduza o seu elemento material - a sua 'carne', no sentido em que o Estado hegeliano incarna a eticidade, ou a sua alma - o Volksgeist, de que falaram Herder, Savigny e tantos outros -, mas porque é a formalidade do ordenamento jurídico que determina a validade das suas próprias normas, ao determinar quais são, a partir da Constituição, as autoridades que possuem capacidade ou competência, assim como os procedimentos a que devem obedecer, para as integrar no mesmo ordenamento. Sem dúvida, essa validade supõe a eficácia global do sistema, isto é, o assentimento, por concordância ou por receio da punição. Mas há ordens eficazes que não são de direito, como demonstra qualquer organização mafiosa. A ordem jurídica, ou estatal, requer a objetividade das suas normas, ou seja, a sua validade formal, cujo fundamento último remonta à Constituição e à norma segundo a qual a Constituição é uma norma válida. Em termos espinosistas, diríamos que a sociedade se organiza como se fosse a partir de uma só norma, sendo que este mesmo como se, ou veluti, confere unidade e realidade ao Estado, enquanto corpo de normas que se auto-regula. 
À semelhança do que acontece na obra de Espinosa, o Estado kelseniano é sem exterior, o que inibe, aliás, a distinção habitual entre Estado de direito e outros tipos de Estado. Com efeito, não existe Estado se não existir direito, e não existe direito sem um princípio que fundamente as normas. Ora, do ponto de vista do conhecimento esse princípio é meramente formal, ou relacional, não traduzindo nenhuma essência ou valor de onde se inferisse o conteúdo do que será prescrito. Em última instância, a multidão enquanto Estado civil está refém de uma hipótese, a hipótese de que a sua potência se traduz em determinado ordenamento jurídico, o qual funciona se, e enquanto, tal hipótese for reconhecida. É certo que a potência da multidão emerge na imaginação de cada um completamente transfigurada. Enquanto no Estado de natureza ela se confundia com uma multiplicidade de indivíduos que interagiam de múltiplos modos, estabelecendo entre si relações de maior ou menor dependência e domínio, aqui, ela surge como potestas, como poder separado, que a todos transcende e por isso eles lhe guardam obsequium. Empiricamente, a potência da multidão é de fato uma amálgama de paixões e interesses, cuja resultante se consolida sob determinada configuração institucional. Mas as configurações em que a potência do múltiplo se dá são sempre tensões. O assentimento dos indivíduos às normas mistura-se com a revolta e a conspiração, que só o medo contém. Por esse motivo, 'a multidão que se conduz como se fosse uma só mente' não se explica apenas como simples convergência/divergência de afetos, transfigurada pela imaginação numa instância separada e com poder de afetar, por sua vez, a conduta de cada um (Cf. London, 2008). A sua inteligibilidade como Estado requer, inevitavelmente, que ela se pense como unidade, mesmo sabendo que essa unidade, empiricamente, não se dá senão como divisão. Conforme Wittgenstein afirma, "há certas proposições [que] estão subtraídas à dúvida, como rodízios em torno dos quais rodam as certezas e as dúvidas" (Wittgenstein, 1998, \$41). É esse o estatuto da fórmula una veluti mente. 
Referências bibliográficas

AA. V. Hermann Cohen's Critical Idealism (Amsterdam Studies in Critical Philosophy), Springer Verlag, 2005.

AA. V. Hermann Cohen. L'idealisme critique aux prises avec le matérialisme, Revue de Métaphisique et de Morale, n. 1, jan. 2011.

BALIBAR, E. Spinoza et la politique. Paris, PUF, 1985.

BLOCH, O. Spinoza au XXe Siècle. Paris, PUF, 1993.

COHEN, H. Logik der reinen Erkenntnis [1904]. Hildesheim/ New York: Georg Olms, 1977. . "Spinoza über Staat und Religion, Judentum und Christentum", Jahrbuch für Geschichte und Literatur, 18, 1915, pp. 56-151. Trad. franc. in Leo Strauss, Le Testament de Spinoza, 1991.

EDEL, G. Von der Vernunftkritik zur Erkenntnislogik. Die Entwicklung der theoretischen Philosophie Hermann Cohens, Waldkirsh: Edition Gorz, 2010.

ESPINOSA, B. Tratado político. Trad. Lelia Pezillo (Roma-Bari: Laterza, 1995); Atilano Dominguez (Madrid: Alianza Editorial, 2004); Charles Ramond (Paris: PUF, 2005); Émile Saisset (Paris: Le Livre de Poche, 2002); Diogo Pires Aurélio, (São Paulo: Martins Fontes, 2009); Samuel Shirley (Indianopolis: Hackett Publishing Company, 200o); Omero Proietti, (Opere, Milano: Mondadori, 2007); Wolfgang Bartuschat (Politischer Traktat, Hamburg: Felix Meiner Verlag, 2010).

Tratado teológico político. Trad. Diogo Pires Aurélio. Lisboa: INCM, 2004.

ESPOSITO, R. Communitas. Origine e destino della communità. Torino: Einaudi, 2006.

CAMmarota, G. P. L'idealismo messiânico de Hermann Cohen. Napoli: Edizioni Scientifiche Italiani, 2002.

GIL, F. La conviction. Paris: Flammarion, 2000.

GOYARD-FABRE, S. "De l'idée de norme à la science des normes. Kant et Kelsen”. In: AMSELEK, P. (org.). Théorie du droit et science. Paris: PUF, 1991, pp. 95-126. 
GUSTAFSSON, K. "Fiction of Law I", NoFO, out. 2007, p. 86.

HAYEK, F. Droit, Législation et Liberté. v. 2 [Le mirage de la justice sociale]. Trad. Raoul Auduin. Paris: PUF, 1982.

HOBBES, T. A Dialogue between a Philosopher and a Student, of the Common Laws of England [1681]. In: MOLESWORTH, W. (1839-1845) (ed.). The English Works. Vol. VI, rep. London: Scientia Verlag Aalen, 1965.

Leviathan, sive de Materia, Forma et Potestate Civitatis ecclesiasticae et civilis [1668]. MOLESWORTH, G. (1839-1845) (ed.). In: Opera Philosophica quae latine scripsit. Vol. III, rep. London: Scientia Verlag Aalen, 1966.

KANT, I. Crítica da razão pura. Trad. Manuela Pinto dos Santos e Alexandre Fradique Morujão. Lisboa: Fundação Calouste Gulbenkian, 1994.

KELSEN, H. "Das Problem des Parlamentarismus" [1925]. "O problema do parlamentarismo". In: KELSEN, H. A Democracia. Trad. Ivone Castilho Benedetti, Jefferson Luiz Camargo, Marcelo Brandão Cipolla, Vera Barkow. São Paulo: Martins Fontes, 2000, pp. 109-135.

General Theory of Law and State [1949]. New Brunswick: Transaction Publishers, 2006.

Reine Rechtslehre [1960, $2^{\mathrm{a}}$ ed.]. Teoria Pura do Direito. Trad. João Baptista Machado. Coimbra: Almedina, 2008.

Allgemeine Theorie der Normen [1979]. Théorie Générale des Normes. Trad. Beaud O. Paris: PUF, 1996.

LAZZERI, C. Droit, pouvoir et liberté. Spinoza critique de Hobbes. Paris: PUF, 1998.

LORDON, F. "Derrière l'idéologie de la légitimité, la puissance de la multitude”. In: JACQUET, C.; SÉVÉRAC, P.; SUHAMY, A. (org.). La multitude libre. Nouvelles lectures du Traité Politique. Paris: Éditions Amsterdam, 2008, pp. 105.129. MAQUiAVEL, O Príncipe. Trad. Diogo Pires Aurélio. Lisboa: Círculo de Leitores, 2008. 
MARRAMAO, G. Potere e secularizzazione. Le categorie del tempo. Torino: Bollati Boringhieri, 1985.

MATHERON, A. "L'indignation et le conatus spinoziste". In: REVAULT D’ALLONES, M.; RIZK, H. Spinoza: Puissance et Ontologie. Paris: Kime, 1994, pp. 153-165.

MONTAG, W. Bodies, Masses, Power. Spinoza and its contemporaries. London: New Verso, 1999.

MÜNSTER, A. L'école de Marbourg. Le neo-kantisme de Hemann Cohen vers le socialisme éthique? Paris: Kimé, 2005.

NEGRI, A. "Reliqua desiderantur: Congettura per una definizione del concetto di democrazia nell'ultimo Spinoza", Studia spinozana, 1, n. 8, 1985 .

. "Reliqua desiderantur: Conjecture pour une définition du concept de démocratie chez le dernier Spinoza" (1985). In: Spinoza Subversif. Paris: Kimé, 1994.

NORDMANN, S. Du singulier à l'universel. Essai sur la philosophie religieuse de Hermann Cohen. Paris: Vrin, 2007.

POMA, A. La filosofia critica de Hermann Cohen. Milano: Ugo Mursia Editore, 1988.

SCHMITT, C. Der Leviathan in der Staatslehre des Thomas Hobbes. Sinn und Fehlschlag eines politischen Symbols [1938]. Le Léviathan dans la Doctrine de l'État de Thomas Hobbes, Sens et échec d' un symbole politique. Trad. D. Trierweiler. Paris: Seuil, 2002.

Die Diktatur [1921] La dictature. Trad. Mira Köller e Dominique Séglard. Paris: Seuil, 2000.

STRAUSS, L. "Cohen's Analyse der Bibel-Wissenschaft Spinozas”. Der Jude. Berlin, VIII 5/6, mai./ jun., 1924, pp. 295-314. Trad. franc. in Leo Strauss, Le testament de Spinoza, Paris: Les Editions du Cerf, 1991, pp. 51-78.

TOSEL, A. Spinoza ou l'autre (in)finitude. Paris: L'Harmmatan, 2008.

VAIHINGER, H. Die Philosophie des Als Ob [1923]. La philosophie du comme si. Trad. C. Bouriau. Paris: Editions Kimé, 2008. 
WALTHER, M. "Spinoza und der Rechtspositivismus". In: GIANCOTTI, E. (ed.). Proceedings of the First Italian International Congress on Spinoza. Napoli: Bibliopolis, 1985, pp. 401-418.

WITTGEnSTEIN, L. Da Certeza. [Parag. 41]. Trad. Maria Elisa Costa. Ed. bilingue. Lisboa: Edições 70, 1998. 
